\title{
Taxpayer's Perception to Tax Payment in Kind System in Support of SMEs' Sustainability: Case of the South Korean Government's Valuation of Unlisted Stocks
}

\author{
KapSoon Kim ${ }^{1}$ and SungMan Yoon ${ }^{2, *}$ \\ 1 School of Business, Dongguk University (Seoul), 30, Pildong-ro 1-gil, Jung-gu, 04620 Seoul, Korea; \\ kks@dongguk.edu \\ 2 Department of Business Administration, Seoul National University of Science and Technology, 232 \\ Kongneung-ro, Nowon-gu, 01811 Seoul, Korea \\ * Correspondence: ysm6123@seoultech.ac.kr; Tel.: +82-970-6440
}

Received: 4 August 2017; Accepted: 24 August 2017; Published: 26 August 2017

\begin{abstract}
In Korea, unlisted stock shares are accepted as payment for inheritance tax. In the case of insufficient cash, a taxpayer can pay the government with listed or unlisted stocks (hereinafter referred to as "tax payment in kind"). The drawback of this tax payment system is that receiving tax paid with stocks is subject to the valuation of the government and selling the stocks to an open market requires another valuation. The results of these two valuations show considerable differences, and, therefore, the selling price in the open market is very low. This study analyzes how taxpayers recognize the differences in the valuation results of these unlisted stocks and how the differences affect the pricing for repurchasing the stocks from the open market. Results show that high valuation of unlisted stocks in tax payment in kind drives buyers to lower the purchasing price in the open market. This finding implies a problem in the government's valuation method of unlisted stocks collected as tax.
\end{abstract}

Keywords: SMEs sustainability; tax practitioner's advice; unlisted stock; stock valuation; tax payment in kind

\section{Introduction}

In principle, taxes should be paid in cash [1,2], but, in Korean tax law, if certain requirements are met, payment can be made with real estate or stocks, which is called tax payment in kind [3]. In the past, inheritance, gift, corporate and individual income, and comprehensive property taxes were recognized as tax items that can be paid in kind. Since 2008, tax payment in kind is only allowed for inheritance and property taxes. Tax payment in kind means an individual taxpayer pays inheritance tax with securities, such as government and public bonds, and listed or unlisted stocks of small- and medium-sized enterprises (SMEs) [1,2,4]. In this tax payment system, individual taxpayers who have insufficient cash to pay tax are permitted to use certain assets for payment, and the government face possible side effects, such as tax avoidance or moral hazard.

In addition, the market price or fair value of unlisted stocks is difficult to measure [5]. By contrast, the fair value of listed stock can be identified because the stocks are traded in the stock market (with stock market price). The fair value of unlisted stocks cannot be easily identified because an active market for these stocks does not exist [6]. Ohlson [7] argues that a linear relationship exists between accounting information and firm value, and, thus, the unlisted stocks' value can be estimated using accounting information of the current unlisted corporation. In particular, according to the residual income model (RIM), the firm value can be estimated as the sum of the current book value and the present values of future expected excess profits [5]. 
RIM is based on the assumption that current excess profits will be obtained continuously in the future, and this assumption is restrictive when it comes to evaluating the value of a corporation [8]. The capital cost must be established to apply the appropriate discount rate to the excess profit, making the stock price of the company difficult to determine. Many previous studies explored the valuation of companies. Tax payment in kind supporting SMEs is based on unlisted stocks valued at the receipt and sale point by the government or government-owned entity $[1,2]$. Whether tax payment in unlisted stocks can effectively assist the succession to family-owned SMEs should be investigated. This study investigates the entire process of tax payment in kind, in which the government evaluates the value of unlisted stocks, stores them, and eventually sells the stocks to an open market. This study focuses particularly on the relationship between the valuation of the government when receiving unlisted stock from taxpayers and buyers' stock repurchase price when selling in the open market.

Despite the distinctive characteristics of tax payment in kind system, few papers to date have attempted to document taxpayers' perception of this system to assess its validity and efficiency. The current study possesses novelty in that it is the first to analyze taxpayers' perception of the payment system to support SMEs' sustainability. Another contribution of this study is confirming the need for fair governmental valuation for SMEs' sustainability. This paper is organized as follows. Section 2 reviews the tax payment in kind system and presents the research question. Section 3 outlines the methodology, including the measurement of variables, extraction of research materials, and presentation of descriptive statistics. Section 4 presents the empirical results. Section 5 summarizes the study and presents its political implications.

\section{Tax Payment in Kind System and Research Question}

\subsection{System of Tax Payment in Kind}

The tax payment in kind system (TPKS) of Korea is applied only to inheritance and property taxes. When taxpayers pay tax for inherited property (e.g., cash, stock, bond, building, and land), they pay in kind with unlisted stocks or real estate in the case of insufficient cash [9]. The TPKS has been implemented not only in Korea but also in Germany, England, and Japan [10-12]. In the case of the United States, this system is unnecessary because the government does not impose taxes on inheritance of SMEs [11,12]. Given the objectivity and impartiality of the valuation of unlisted stocks, TPKS is now applied only in Korea and Japan [3,9].

Figure 1 illustrates the flowchart of the TPKS in Korea (This study analyzes the situations in which the payment mode of TPKS is unlisted stocks. In the case of real estate, bidding in most public markets leads to a purchase by an unspecific number of potential buyers. With regard to listed stock, the public sale is not made in the stock market as market price, and, therefore, the issue of tax avoidance does not occur.). First, the government accepts unlisted stocks instead of cash from a taxpayer. The value of unlisted stocks is evaluated according to the inheritance tax law to determine the price per unlisted stock and number of stocks. Unlisted stocks have no market price, so the stock price is determined according to past firm performance and future cash flow, and the number of stocks is determined to match the amount equivalent to inheritance tax $[1,9,13]$. Tax authority evaluates the unlisted stock value through weighted averaging of past net asset values and profit values by (2)3. The net asset value is calculated by dividing net assets at the valuation date by the total number of issued shares, and the profit value is measured by dividing the net income (loss) of the past three years by the return rate $[9,13]$. As a result, at the tax collection stage, the evaluation of unlisted stocks is based on past earnings or net asset data, failing to effectively reflect the future cash flows or firm value of SMEs.

Second, the government entrusts the unlisted stocks received from taxpayers to a government-owned enterprise (GOE) (this institution is the Korea Asset Management Corporation (KAMCO)) for consignment and disposal in open markets. The GOE valuates consigned unlisted stocks in accordance with the government property management law (GPML), and its valuation method is significantly different from that of inheritance and gift tax law. Inheritance gift tax is evaluated by firm 
performance in the past three years according to inheritance and gift tax law, but the GPML evaluates the value with the estimated future business results, including the year of valuation. Therefore, the price when the same unlisted stock is paid to the government greatly differs from the estimated price offered in an open market. At this stage, unlisted stock valuation is similar to the valuation at the tax collection stage, but the disposal amount of the unlisted stock likely increases to favor the government. The government assigns a weighted value of (3)2 to the asset and revenue values, which is greater or less than the asset value, and evaluates unlisted stocks based on expected future cash flows or returns rather than historical data. As a result, the value of the same unlisted stock at the disposal stage is overestimated more than four times from the tax collection stage [3].

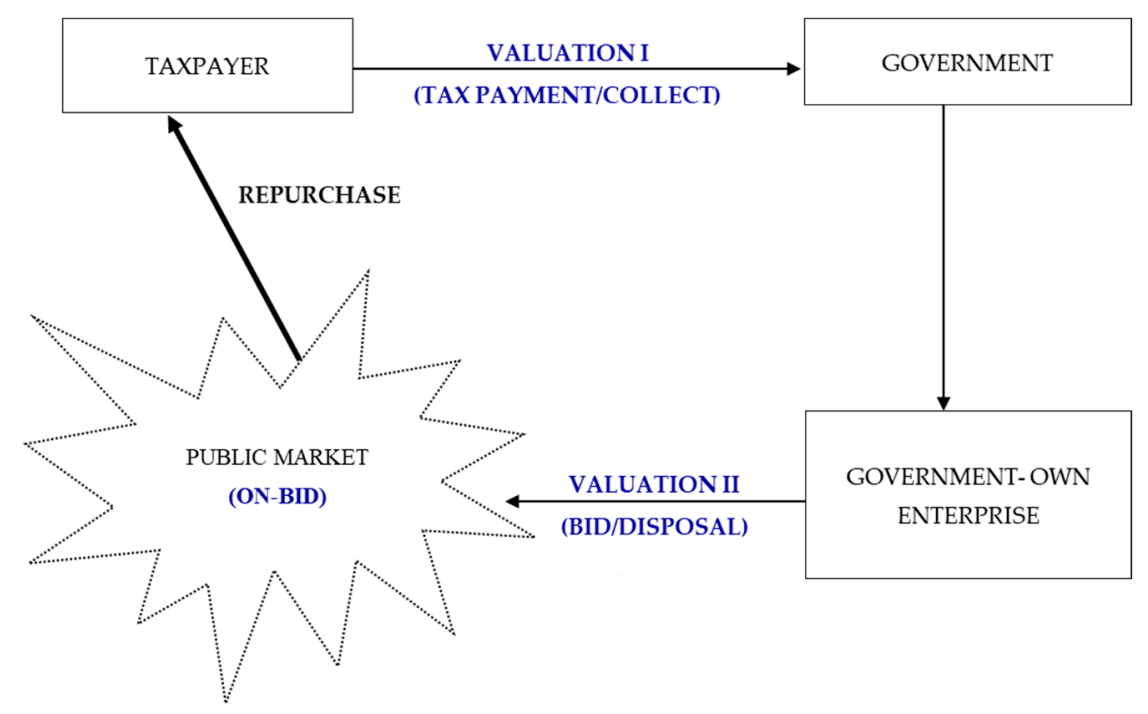

Figure 1. The System of Tax Payment in Kind.

Third, the GOE sells the unlisted stocks to a public market with ON-BID system at the price determined by such valuation. Unspecified number of prospective buyers cannot judge the appropriate purchase price because of the insufficient information on the stock of a company that is not part of IPO. In addition, if the company pays tax in kind, then the open market judges this as a sign that the company founder or previous managements will change, and, therefore, purchasing the unlisted stock in the open market presents no incentive. In most cases, unspecified buyers do not purchase such a stock; rather, the taxpayer who made this tax payment in kind buys the unlisted stock.

\subsection{Research Question}

In disposing national securities acquired through tax payment in kind, the conversion rate (value of unlisted stocks/value of unlisted stocks) is very low because the disposal or demand of unlisted stocks through in-house transactions is limited, unlike that of listed stocks. For unlisted stocks to be used as payment for national tax, estimated selling prices, which are calculated through annual valuation every year, are determined by a securities subcommittee and subsequently sold to the public through a public bidding system (ON-BID) $[1,2,14]$.

Given the characteristics of most tax payment in kind companies, which are SMEs and family businesses, the demand is limited or the stocks are not sold for a long time or sold at low prices. As shown in the table, the conversion rates in recent years (January to July 2015) were $31.8 \%$, and the average rate was only $66.1 \%$ from 2010 to July 2015. In 2014, the exchange rate was $156 \%$, which was unusual, and this was because the stocks of the companies with large tax payment in kind were sold higher than the value of tax payment in kind (However, the price of most unlisted stocks paid in kind is considerably lower than their selling price. Company $A$ paid in kind unlisted stocks worth 15.8 billion KRW, and these unlisted stocks were sold for 43.0 billion KRW. Company $B$ shows the 
same numbers as Company $A$. Company $C$ paid in kind unlisted stocks worth 0.5 billion KRW, which were sold for 20 billion KRW. Unusual phenomena are noted in which the unlisted stocks were sold higher than their value at the time of tax payment.).

The reasons for the low unlisted stocks' sales to tax payment ratio (Sales/Tax Payment) are as follows. First, considerable information asymmetry exists between publicly traded disposal agencies, tax payment in kind companies, and buyers in the unlisted stock trading market. An unlisted company has enough reliable information to evaluate the fair value of the company. However, from a buyer's $\mathrm{s}$ viewpoint, using this information is difficult in reality.

Second, due to the information asymmetry between unlisted companies and buyers, a structural problem arises in which the buyers decide the price because buyers who purchase unlisted stocks are limited. Unlisted stocks paid in kind are sold through auction. In most cases, possible buyers who are likely to buy these stocks are the taxpayers who paid tax in kind. The taxpayers purchase the stocks through a veteran contract at the lowest level of selling price after a number of bidding failures during the auction (Predetermined price in the public sale disposal stage is about four times higher than the value of unlisted stocks at stage of collection with tax payment in kind. This shows that the high bidding prices of the buyers including the company that paid the tax in kind will act to restrict the incentive to buy the unlisted stocks, and subsequently lead continuous bidding failure and price reduction and eventually, will be traded at lower price than selling price.).

Third, the complementary valuation method in inheritance and gift tax law, which is a valuation method for calculating the value of the tax payment in kind, greatly differs from the estimated selling price calculation method in GPML, which is a valuation method for selling. Claiming that a reliable fair pricing for trading unlisted stocks used to pay tax is farfetched [2,9]. As the estimated selling price at the disposal stage in public auction (which is only a few months later) is estimated to be more than four times higher than the unlisted stock price evaluated at the collection stage of tax payment in kind, a buyer cannot rely that the estimated selling price is fair. In addition, the selling price drops to the lowest level through multiple bidding failures using the monopolistic structure of demand, which causes inefficiency, such as extension of the transaction period. An illusion phenomenon occurs when the selling price looks very low compared with excessively high estimated selling price.

In the event of a large temporary tax burden, taxpayers can execute their tax obligations without disposing their assets at a low price by paying tax in kind, and the government can secure the tax receivable. Therefore, the TPKS is regarded as a useful method for tax payment and collection. In reality, as the problems of national treasury loss continuously rises in spite of this efficient TPKS, appropriate solutions are required through valuation method of unlisted stocks, appropriateness of management and disposal standards and improvement of preventive measures for the exploitation of expedient inheritance and bestowal or tax avoidance.

In the immersive viewpoints of Reichheld and Sasser [15], a buyer's intention to repurchase products and services means that the buyer intends to maintain a consistent relationship through the results of comparative analysis of benefits and costs. Marketing-related research emphasizes the importance of repurchase intention as a factor to increase the profit of company because customers can be secured through determinant $[2,9]$.

Rusbult and Ferrel [16] confirmed the importance of repurchase intention in their representative study on organization behavior. The results show that repurchasing intention affects business performance by maintaining the relationship between the customers and company [16]. Repurchase intention is mainly explained to be created by buyer satisfaction. That is, overall satisfaction creates positive emotions and responses that influence a buyer's behavioral intention, and customer satisfaction can be a key factor in creating repurchase intention $[2,9,17]$. Buyers' intention to repurchase products or service can vary depending on their satisfaction and perception of the goods or services. Likewise, in the case that a taxpayer repurchases the unlisted stocks used to pay inheritance tax, the repurchase price may vary depending on the satisfaction with the valuation of the unlisted stocks. 
The taxpayer's satisfaction with the valuation of the unlisted stocks at the time of tax payment affects the repurchase price of unlisted stocks in the open market [2]. If the taxpayer recognizes the valuation result (tax payment in kind value) to be reasonable or appropriate, then the open market will recognize that the repurchase price of the taxpayer is similar to the tax payment in kind value.

However, if the government highly evaluates the value of unlisted stocks, then the repurchase price of the taxpayer will be lower than the initial tax payment in kind value. This study establishes the following research question by analyzing the relationship between the evaluation results of taxpayers when paying unlisted stocks to the government and their recognition of the repurchase price level of the unlisted stocks.

Research Question: Is the repurchase price of unlisted stocks related to the valuation results of unlisted stocks in the tax payment in kind system?

\section{Materials and Methods}

\subsection{Research Model}

In terms of respondent levels, repurchase prices are classified into different proportion categories (i.e., $60-70 \%, 70-80 \%, 80-90 \%, 90-100 \%, 100-120 \%$, and more than $120 \%$ of tax payment in kind). These categories are typically considered as ordinal outcomes (i.e., from lowest level at $60-70 \%$ of tax payment in kind to the highest level as more than $120 \%$ of tax payment in kind). Ordered discrete choice models are generally used to analyze such ordinal response data. Among these models, the ordered probit (OP) is the most commonly used approach $[18,19]$. Let $\mathrm{y}_{n i}$ be repurchase price $n$ by respondent $i$. The OP model assumes that repurchase price level can be represented by a latent and continuous variable $\left(\mathrm{y}_{n i}^{*}\right)$, which is related to $\mathrm{X}_{n i}$ given as:

$$
\mathrm{y}_{n i}^{*}=\mathrm{X}_{n i} \beta+\varepsilon_{n i} \forall_{i}
$$

where $X_{n i}$ is a vector of explanatory variables, $\beta$ is a vector of unknown parameters to be estimated, and $\varepsilon_{n i}$ is the random error term capturing the effect of unobserved factors, which is assumed to follow a normal distribution with zero mean and unit variance [18,19].

In the respondent's survey data presented in this study, the repurchase prices of taxpayers (SMEs) are scaled to six price levels: (1) $60-70 \%$; (2) $70-80 \%$; (3) $80-90 \%$; (4) $90-100 \%$; (5) $100-120 \%$; and (6) more than $120 \%$ of tax payment in kind. The dependent variables (i.e., experience, initial valuation, tax advice, and tax avoidance) are then ordered with several categories.

For repurchase price $n$ to occur from respondent $i$, the observed repurchase price level $\left(\mathrm{y}_{n i}\right)$ is related to an unobserved (latent) variable $\left(\mathrm{y}_{n i}^{*}\right)$ and is expressed as follows:

$$
\mathrm{y}_{n i}=\mathrm{j} \Rightarrow \mu_{j-1} \leq \mathrm{y}_{n i}^{*} \leq \mu_{j} \Leftrightarrow\left(\begin{array}{c}
1 \text { if } 60 \%<\mathrm{y}_{n i}^{*} \leq 70 \% \text { of tax payment in kind } \\
2 \text { if } 70 \%<\mathrm{y}_{n i}^{*} \leq 80 \% \text { of tax payment in kind } \\
3 \text { if } 80 \%<\mathrm{y}_{n i}^{*} \leq 90 \% \text { of tax payment in kind } \\
4 \text { if } 90 \%<\mathrm{y}_{n i}^{*} \leq 100 \% \text { of tax payment in kind } \\
5 \text { if } 100 \%<\mathrm{y}_{n i}^{*} \leq 120 \% \text { of tax payment in kind } \\
6 \text { if } \mathrm{y}_{n i}^{*}>120 \% \text { of tax payment in kind }
\end{array}\right.
$$

where $j$ is the number of repurchase price levels (in this case, $j=6$ ); $\mu_{1}, \mu_{2}, \mu_{3}, \mu_{4}$, and $\mu_{5}$ are unknown threshold parameters to be estimated [18-20]. The predicted probabilities of the repurchase price level $j(j=1,2,3,4,5,6)$ for given $X_{n i}$ can be estimates as:

$$
\mathrm{P}\left(\mathrm{Y}_{n i}=\mathrm{j}\right)=\mathrm{F}\left(\mu_{j}-\mathrm{X}_{n i}^{\prime} \beta\right)-\mathrm{F}\left(\mu_{j-1}-\mathrm{X}_{n i}^{\prime} \beta\right)
$$


where $\mathrm{F}(\cdot)$ is the standard normal cumulative distribution function. The model parameters (e.g., $\beta$ and $\mathrm{y}_{n i}^{*}$ are estimated by the method of maximum likelihood [18-20]. The marginal effects of the ordered probit model with respect to explanatory variable $l\left(\beta_{l}\right)$ can be estimates as:

$$
\mathrm{ME}_{J l X l}=\frac{\partial \mathrm{P}\left(\mathrm{Y}_{n l}=\mathrm{jX} \mathrm{X}_{n i}\right)}{\partial X_{I l}}=\left[f\left(\mu_{j-1}-X_{n i}^{\prime} \beta\right)-f\left(\mu_{j}-X_{n i}^{\prime} \beta\right)\right] \cdot \beta_{l}
$$

where $f(\cdot)$ is the density function.

This study investigates whether the valuations results of unlisted stocks in the TPKS affect taxpayers' repurchase price. To verify the research question, the research model is set similar to Equations (5) and (6). Equation (5) is a research model to verify a difference in pricing the unlisted stocks in the TPKS between the tax authority and taxpayers (SMEs). Dependent variable (Repurchase_Price) is measured by the taxpayers' response to the repurchase price of unlisted stocks, which is the tax payment paid in kind measured by a 6-point Likert scale [15]. Regarding interest variable (Experienced_Taxpayer), if the taxpayer has an experience to pay tax in kind with unlisted stock, then the value is 1 . If the taxpayer is a tax practitioner or taxation professor, then the value is 0 .

Regarding Tax_Avoidance as control variable, if the taxpayer's reason for the discontinuance of TPKS for previous gift tax is tax avoidance, then the variable is given a value of 1 ; otherwise, 0 . For GiftTax_Adoption, if the taxpayer responds that the TPKS by unlisted stock should also be adopted for future gift tax, then the variable is given a value of 1 ; otherwise, 0 . Regarding TPKS_Favorable, if the taxpayer recognizes that TPKS by unlisted stock is more advantageous to the taxpayer than cash payment, then the variable is given a value of 1 ; otherwise, 0 . For Additional_Exp, if the taxpayer is open to additional costs when paying the tax in kind with unlisted stocks in the future, then the variable is given a value of 1 ; otherwise, 0 . Career represents the number of service years of the responding taxpayer.

$$
\begin{gathered}
\text { Repurchase_Price } \mathrm{i}=\beta_{0}+\beta_{1} \text { Experienced_Taxpayer }_{i}+\beta_{2} \text { Tax_Avoidance }_{i}+ \\
\beta_{3} \text { GiftTax_Adoption }_{i}+\beta_{4} \text { TPKS_Favorable }_{\mathrm{i}}+\beta_{5} \text { Additional_Exp }_{\mathrm{i}}+\beta_{6} \text { Career }_{i}+\beta \sum \text { Location }_{i}+\varepsilon_{i}
\end{gathered}
$$

Equation (6) is a research model targeting taxpayers with experience in paying tax in kind with unlisted stocks. This model is used to analyze whether the valuation results of the unlisted stocks the taxpayer paid in kind to the government affect the repurchase price of the stocks.

Similar to the dependent variable (Repurchase_Price) in Equation (5), this variable is the taxpayer's response to the repurchase price of unlisted stocks which is paid in kind and measured by a six-point Likert scale. Interest variable is Initial_Valuation and is measured at the price level evaluated by the government when paying the tax in kind with unlisted stocks using a five-point Likert scale.

Regarding Tax_Advice, if the taxpayer has experienced receiving tax advice from a tax agent about tax payment in kind when paying inheritance tax with unlisted stocks in the past, then the variable is given a value of 1 ; otherwise, 0 .

$$
\begin{gathered}
\text { Repurchase_Price }_{i}=\beta_{0}+\beta_{1} \text { Initial_Valuatoin }_{i}+\beta_{2} \text { Tax_Advice }_{i}+\beta_{3} \text { Tax_Avoidance }_{i}+ \\
\beta_{4} \text { GiftTax_Adoption }_{i}+\beta_{5} \text { TPKS_Favorable }_{i}+\beta_{6} \text { Addditional_Exp }_{i}+\beta_{7} \text { Career }_{i}+\beta \sum \text { Location }_{i}+\varepsilon_{\mathrm{i}}
\end{gathered}
$$

where

Repurchase_Price $=$ The repurchase price level of a taxpayer (corporation), measured at six-point Likert scale as follows: (1) 60 70\% of tax payment in kind; (2) 70 80\% of tax payment in kind; (3) $80 \sim 90 \%$ of tax payment in kind; (4) 90 100\% of tax payment in kind; (5)100 120\% of tax payment in kind; and (6) more than $120 \%$ of tax payment in kind.

Experienced_Taxpayer $=$ If the respondent is a taxpayer (corporation) has an experience to pay tax in kind, " 1 "; otherwise, " 0 ". 
Initial_Valuation $=$ The response of the taxpayer (corporation) about the valuation when paying the tax in kind with unlisted stock and is measured as five-point Likert scale: (1) very low level; (2) low level; (3) medium level; (4) high level; and (5) very high level.

Tax_Advice $=$ If the taxpayer receives tax advice from tax professional when paying the tax in kind with unlisted stock, " 1 "; otherwise, " 0 ".

Tax_Avoidance $=$ If the taxpayer responded that the reason why the discontinuance of tax payment in kind system of the unlisted stock for previous gift tax is the tax avoidance, " 1 "; otherwise, " 0 ".

GiftTax_Adoption = If the taxpayer responds that tax payment in kind system by unlisted stock should be adopted again for future gift tax, "1"; otherwise, " 0 ".

TPKS_Favorable = If the taxpayer thinks that tax payment in kind system by unlisted stock is more advantageous to the taxpayer than cash payment, "1"; otherwise, " 0 ".

Additional_Exp $=$ The level of intention to take additional costs when paying the tax in kind with current unlisted stocks, and is measured as five-point Likert scale: (1) not likely at all; (2) not likely; (3) normal; (4) likely yes; and (5) highly likely.

Career $=$ The number of service years of the respondent and measured as five-point Likert scale as follows: (1) less than five years; (2) from five to less than seven years; (3) from seven to less than 10 years; (4) from 10 to less than 15 years; and (5) more than 15 years.

$\Sigma$ Location $=$ dummy variable for each metropolitan city in Korea.

\subsection{Sample Selection}

Samples of this study were collected in May 2015, targeting the members of Korean Academic Society of Taxation (KAST) who are tax professionals, including tax lawyers, tax accounting professors, public economics professors, and taxpayers (SMEs) who have experienced using the TPKS with unlisted stock. An online-based questionnaire survey was used in this study. Measurements used in this survey were adopted from previous studies and were modified to suit the research context. We e-mailed the questionnaire to all KAST members. Upon receiving the list of SMEs with experience in repurchasing their unlisted stocks from KAMCO, we e-mailed these SMEs with the deadline.

Table 1 shows the distribution of survey respondents. The respondents are $197 \mathrm{in}$ total, including 131 (12\% of all members) tax professionals from KAST and 66 taxpayers (SMEs) with experience in paying tax in kind. Respondents with less than five years of service are 33.5\% (66 respondents) and those with more than 15 years of service are $29.95 \%$ (59 respondents).

Table 1. Sample distribution.

\begin{tabular}{cccc}
\hline Career Years & Tax professional & Experienced Taxpayer & Total \\
\hline Less than 5 years & 54 & 12 & $66(33.50 \%)$ \\
$5-7$ years & 11 & 9 & $20(10.15 \%)$ \\
$7-10$ years & 17 & 7 & $24(12.18 \%)$ \\
10-15 years & 17 & 11 & $28(14.21 \%)$ \\
More than 15 years & 32 & 27 & $59(29.95 \%)$ \\
Total & 131 & 66 & $197(100.00 \%)$ \\
\hline
\end{tabular}

\section{Analysis and Results}

\subsection{Descriptive Statistics and Correlation}

Table 2 shows the descriptive statistics of samples. The average of Repurchase_Price of all respondents is 3.701 , and that of taxpayers (SMEs) is 2.470 , which is relatively lower. These results indicate that taxpayers with experience to pay tax in kind have a higher tendency to repurchase the unlisted stocks paid by the taxpayers with lower price than tax professionals. 
Table 2. Descriptive statistics.

\begin{tabular}{llccccccc}
\hline & Variables & Mean & Std & Min & Q1 & Med. & Q3 & Max \\
\hline \multirow{4}{*}{ All } & Repurchase_Price & 3.701 & 1.737 & 1 & 2 & 4 & 5 & 6 \\
respondents & Experienced_Taxpayer & 0.335 & 0.473 & 0 & 0 & 0 & 1 & 1 \\
$(n=197)$ & Tax_Avoidance & 0.629 & 0.484 & 0 & 0 & 1 & 1 & 1 \\
& GiftTax_Adoption & 0.208 & 0.407 & 0 & 0 & 0 & 0 & 1 \\
& TPKS_Favorable & 0.848 & 0.36 & 0 & 1 & 1 & 1 & 1 \\
& Additional_Exp & 3.518 & 1.095 & 1 & 3 & 4 & 4 & 6 \\
& Career & 2.944 & 1.679 & 0 & 1 & 3 & 5 & 5 \\
\hline \multirow{5}{*}{ Experienced } & Repurchase_Price & 2.470 & 2.017 & 1 & 1 & 1 & 4 & 6 \\
Taxpayers & Initial_Valuation & 3.485 & 1.243 & 0 & 3 & 4 & 4 & 5 \\
& Tax_Adivce & 0.924 & 0.267 & 0 & 1 & 1 & 1 & 1 \\
& GiftTax_Avoidance & 0.652 & 0.480 & 0 & 0 & 1 & 1 & 1 \\
& TPKS_Favorable & 0.091 & 0.290 & 0 & 0 & 0 & 0 & 1 \\
& Additional_Exp & 0.652 & 0.480 & 0 & 0 & 1 & 1 & 1 \\
& Career & 3.303 & 0.928 & 1 & 3 & 3 & 4 & 6 \\
\hline
\end{tabular}

Note: (1) Definition of the variables is as follows. Repurchase_Price = The repurchase price level of a taxpayer (SMEs), measured at six-point Likert scale as follows: (1) 60 70\% of tax payment in kind; (2) 70 80\% of tax payment in kind; (3) $80 \sim 90 \%$ of tax payment in kind; (4) 90 100\% of tax payment in kind; (5) 100 120\% of tax payment in kind; and (6) more than $120 \%$ of tax payment in kind; Experienced_Taxpayer $=$ If the respondent is a taxpayer (SMEs) has an experience to pay tax in kind, "1"; otherwise, "0". Initial_Valuation = The response of the taxpayer (SMEs) about the valuation when paying the tax in kind with unlisted stock and is measured as five-point Likert scale: (1) very low level; (2) low level; (3) medium level; (4) high level; and (5) very high level; Tax_Advice = If the taxpayer receives tax advice from tax professional when paying the tax in kind with unlisted stock, " 1 "; otherwise, " 0 ". Tax_Avoidance = If the taxpayer responded that the reason why the discontinuance of tax payment in kind system of the unlisted stock for previous gift tax is the tax avoidance, " 1 "; otherwise, "0". GiftTax_Adoption = If the taxpayer responds that tax payment in kind system by unlisted stock should be adopted again for future gift tax, "1"; otherwise, "0". TPKS_Favorable = If the taxpayer thinks that tax payment in kind system by unlisted stock is more advantageous to the taxpayer than cash payment, "1"; otherwise, "0". Additional_Exp = The level of intention to take additional costs when paying the tax in kind with current unlisted stocks, and is measured as five-point Likert scale: (1) not likely at all; (2) not likely; (3) normal; (4) likely yes; and (5) highly likely Career = The number of service years of the respondent and measured as five-point Likert scale as follows: (1) Less than five years; (2) from five to less than seven years; (3) from seven to less than 10 years; (4) from 10 to less than 15 years; and (5) more than 15 years.

In addition, Tax_Avoidance is $62.9 \%$ in total, but that of taxpayers is $65.2 \%$, which is relatively lower.

Table 3 shows the results of the Pearson's correlation among major variables, which are similar to that of Spearman's rank correlation. Repurchase_Price, Initial_Valuation, and Tax_Advice do not show statistically significant results. However, the relevance of these factors should be analyzed after controlling for other factors affecting Repurchase_Price. Taxpayers' tax avoidance tendency, preference for unlisted stocks, expansion of TPKS, and intention to pay additional costs for TPKS can affect the repurchase prices of unlisted stocks. 
Table 3. Pearson's correlation of major variables.

\begin{tabular}{|c|c|c|c|c|c|c|c|}
\hline Variables & $\begin{array}{c}\text { Repurchase } \\
\text { Price }\end{array}$ & $\begin{array}{c}\text { Initial_ } \\
\text { Valuation }\end{array}$ & $\begin{array}{c}\text { Tax } \\
\text { Adivce }\end{array}$ & $\begin{array}{c}\text { Tax } \\
\text { Avoidance }\end{array}$ & $\begin{array}{c}\text { GiftTax } \\
\text { Adoption }\end{array}$ & $\begin{array}{c}\text { TPKS } \\
\text { Favorable }\end{array}$ & $\begin{array}{l}\text { Additional } \\
\quad \text { Exp }\end{array}$ \\
\hline Initial_Valuation & $\begin{array}{l}-0.086 \\
(0.492)\end{array}$ & 1 & & & & & \\
\hline Tax_Advice & $\begin{array}{c}0.153 \\
(0.220)\end{array}$ & $\begin{array}{l}-0.027 \\
(0.831)\end{array}$ & 1 & & & & \\
\hline Tax_Avoidance & $\begin{array}{l}0.251^{* *} \\
(0.042) \\
\end{array}$ & $\begin{array}{l}-0.048 \\
(0.704) \\
\end{array}$ & $\begin{array}{c}0.031 \\
(0.805) \\
\end{array}$ & 1 & & & \\
\hline GiftTax_Adoption & $\begin{array}{c}0.163 \\
(0.192)\end{array}$ & $\begin{array}{c}0.132 \\
(0.291)\end{array}$ & $\begin{array}{l}-0.109 \\
(0.385)\end{array}$ & $\begin{array}{c}0.010 \\
(0.936)\end{array}$ & 1 & & \\
\hline TPKS_Favorable & $\begin{array}{l}0.243^{* *} \\
(0.049)\end{array}$ & $\begin{array}{l}-0.049 \\
(0.694)\end{array}$ & $\begin{array}{l}0.219 * \\
(0.078)\end{array}$ & $\begin{array}{c}0.068 \\
(0.587)\end{array}$ & $\begin{array}{l}-0.104 \\
(0.406)\end{array}$ & 1 & \\
\hline Additional_Exp & $\begin{array}{c}0.045 \\
(0.723)\end{array}$ & $\begin{array}{l}-0.022 \\
(0.862)\end{array}$ & $\begin{array}{l}0.271^{* *} \\
(0.028)\end{array}$ & $\begin{array}{c}0.132 \\
(0.289)\end{array}$ & $\begin{array}{l}-0.101 \\
(0.422)\end{array}$ & $\begin{array}{l}0.413^{* * *} \\
(0.001)\end{array}$ & 1 \\
\hline Career & $\begin{array}{c}0.049 \\
(0.698)\end{array}$ & $\begin{array}{c}0.03 \\
(0.812)\end{array}$ & $\begin{array}{l}-0.177 \\
(0.156)\end{array}$ & $\begin{array}{c}0.028 \\
(0.824)\end{array}$ & $\begin{array}{c}0.018 \\
(0.887)\end{array}$ & $\begin{array}{l}-0.074 \\
(0.557)\end{array}$ & $\begin{array}{c}0.028 \\
(0.824)\end{array}$ \\
\hline
\end{tabular}

Note: $(1)^{* * *}, * *$, and ${ }^{*}$ indicate statistically significant at the $1 \%, 5 \%$ and $10 \%$ two-tailed level, respectively.

(2) Definitions of variables are the same as in Table 2.

\subsection{Results of T-test and Ordered Probit Regression Analysis:}

Regarding the TPKS with unlisted stock, Table 4 shows t-test results between tax professionals and experienced taxpayers. Whether the average distribution of the responses to the same question shows statistically significant difference between tax professionals and experienced taxpayers should be investigated. This study analyzes whether the result of subtracting the average of the response result (b) of the experienced taxpayers from that of tax professionals (a) is statistically significant.

Table 4. T-test result.

\begin{tabular}{lcccccc}
\hline \multirow{2}{*}{ Variables } & \multicolumn{2}{c}{ Tax professionals } & \multicolumn{2}{c}{ Experienced Taxpayers } & \multicolumn{2}{c}{ Difference } \\
\cline { 2 - 7 } & Mean (a) & Std. Dev & Mean (b) & Std. Dev & Mean (a-b) & t-stat. \\
\hline Validity of TPKS & 2.466 & 2.295 & 3.015 & 2.77 & $-0.55^{* * *}$ & -3.67 \\
TPKS Favorable & 1.588 & 0.667 & 2.136 & 0.857 & $-0.549^{* * *}$ & -4.94 \\
Repurchase Price & 4.321 & 1.165 & 2.470 & 2.017 & $1.851^{* * *}$ & 8.15 \\
\hline
\end{tabular}

Note $(1) * * * * *$, and * indicate statistically significant at the $1 \%, 5 \%$ and $10 \%$ two-tailed level, respectively. (2) Definition of the variables is as note1 of Table 2 .

This study obtains statistically significant results in the validity of unlisted stock (validity of TPKS), the level of advantage of TPKS over cash payment, and the average difference of repurchase prices of unlisted stocks, which are paid in kind. Regarding the validity of TPKS and the level of advantage of TPKS, experienced taxpayers show a higher result than tax professionals, and the repurchase prices of unlisted stocks are higher than the valuation by tax professionals. Experienced taxpayers tend to think positively of the TPKS with unlisted stock, but they likely repurchase the unlisted stocks that they paid tax in kind for as low as possible.

Table 5 presents OP regression results to verify the research question. The coefficient of Experienced_Taxpayer is $-0.942(p<0.01)$, which means that taxpayers tend to repurchase the unlisted stocks at a lower price than tax professionals. The marginal effects of Experienced_Taxpayer show that SMEs decrease the probability of increasing repurchase price. 
Table 5. Regression analysis result (all respondents).

\begin{tabular}{lccc}
\hline \multicolumn{1}{c}{ Variables } & Exp. Sign & Coefficient & Wald $\boldsymbol{x}^{\mathbf{2}}$ \\
\hline Experienced_Taxpayer & $+/-$ & $-0.942^{* * *}$ & 13.94 \\
Tax_Avoidance & $+/-$ & $0.674^{* * *}$ & 12.85 \\
GiftTax_Adoption & $+/-$ & $0.640^{* * *}$ & 8.18 \\
TPKS_Favorable & $+/-$ & -0.097 & 0.17 \\
Additional_Exp & $+/-$ & $0.200^{* *}$ & 7.94 \\
Career & $+/-$ & -0.008 & 0.03 \\
\hline Intercepts(1-6) & \multicolumn{3}{c}{ included } \\
Log Likelihood & \multicolumn{3}{c}{-308.591} \\
Number of sample & \multicolumn{3}{c}{197} \\
\hline
\end{tabular}

Note: $(1) * * * * *$, and $*$ indicate statistically significant at the $1 \%, 5 \%$ and $10 \%$ two-tailed level, respectively.

(2) Definitions of variables are the same as in Table 2.

In addition, Tax_Avoidance and GiftTax_Adoption are $0.674(p<0.01)$ and $0.640(p<0.01)$, respectively, which can be interpreted that the respondents who think the reason for abolishing the TPKS for the past gift tax is tax avoidance are more likely to estimate unlisted stock repurchase price high. By contrast, respondents who think that TPKS with unlisted stock should be extended to gift tax in the future are more likely to recognize the repurchase price of unlisted stocks. In particular, Additional_Exp is $0.200(p<0.01)$, which shows that respondents who are willing to pay additional fees for the current unlisted stocks in the TPKS tend to price the purchase unlisted stocks at a higher price.

Table 6 shows the results of OP regression targeting taxpayers (SMEs) who have experienced using unlisted stocks in TPKS. The table shows the effects of Initial_Valuation and Tax_Advice. According to the marginal effects, an increase in the initial valuation results of the tax payment in kind to the government corresponds to a $14.6 \%$ decrease in probabilities of repurchasing the unlisted stocks disposed by the government in an open public market.

Table 6. Regression analysis result (experienced taxpayer only).

\begin{tabular}{lccc}
\hline \multicolumn{1}{c}{ Variable } & Expected Sign & Coefficient & Wald $\chi^{2}$ \\
\hline Initial_Valuation & $+/-$ & $-0.146^{* *}$ & 7.17 \\
Tax_Advice & $+/-$ & $1.323^{*}$ & 3.55 \\
Tax_Avoidance & $+/-$ & $0.779^{* *}$ & 5.17 \\
GiftTax_Adoption & $+/-$ & 0.527 & 0.92 \\
TPKS_Favorable & $+/-$ & $-0.615^{*}$ & 2.58 \\
Additional_Exp & $+/-$ & $0.348^{*}$ & 3.66 \\
Career & $+/-$ & 0.129 & 1.30 \\
\hline Intercepts(1-6) & \multicolumn{4}{c}{-82.201} \\
\hline Log Likelihood & \multicolumn{3}{c}{66} \\
Number of sample & \multicolumn{3}{c}{ included } \\
\hline
\end{tabular}

Note: $(1) \overline{* * * * *}$, and $*$ indicate statistically significant at the $1 \%, 5 \%$ and $10 \%$ two-tailed level, respectively.

(2) Definitions of variables are the same as in Table 2.

Coefficients of Initial_Valuation and Tax_Advice are $-0.146(p<0.05)$ and $1.323(p<0.1)$, respectively, which show that the more the taxpayers think that the value of stock is high when paying tax with unlisted stock, the more they tend to estimate the repurchase price low. The results can also be interpreted that taxpayers who have received advice from tax practitioners about tax payment in kind with unlisted stocks tend to put a high repurchase price on unlisted stocks.

This result shows that if a taxpayer is unsatisfied with the valuation results when paying tax with unlisted stocks, the taxpayer lowers the price of the unlisted stocks when deciding to repurchase. Although the government sets the levied tax with unlisted stocks, it is converted to cash, which is less 
than the amount collected during the public sale by the GOE. The GOE's sale price is smaller than the government's collected tax payment [3].

\section{Conclusions}

Inheritance tax must be paid upon inheriting the stocks of SMEs to their families, such as children with special relationships, due to the death of the founder or former CEO. Inheritance tax is often caused by the sudden occurrence of the property, and, in many cases, the taxpayer, who is the inheritee, lacks cash to pay a huge inheritance tax. The most inherited stocks are SME and unlisted stocks. Considering these characteristics, the government allows the payment of inheritance tax with unlisted stock only under certain conditions, such as lack of cash.

Unlisted stocks are not traded in the active market, and, therefore, issues arise, such as information asymmetry and lack of future certainty of the company. Therefore, the government evaluates the value of the unlisted stocks with a supplementary valuation method. The value of unlisted stocks that reflects the management conditions before the inheritance is overvalued because management performance and financial conditions are reflected in the past three years. However, valuation results of the unlisted stock do not affect the size of the taxpayer's tax burden because the taxpayer pays the tax as much as the valuation amount, which means only the number of stocks is affected. In determining the repurchase price of the unlisted stocks paid for inheritance tax, the repurchase price of the unlisted stock is affected by the valuation result of the unlisted stocks paid to the government. In other words, the greater the valuation at the time of payment, the lower the repurchase price of unlisted stocks.

This study analyzes the price determination factors in repurchasing unlisted stocks in an open market after being used to pay for inheritance tax. The repurchase price of the unlisted stocks shows the opposite sign with the valuation at the payment stage. In addition, when tax advice is received from tax professionals when paying taxes with unlisted stocks, the repurchase price of unlisted stocks increases. Taxpayers can determine the appropriate level of unlisted stocks by consulting tax professionals to ensure that the valuation by the government is appropriate in the case of repurchase.

This study analyzes the situations in which the subject of TPKS is unlisted stock. Real estate is on bid in most public markets, in which unspecified potential buyers are participating. Listed stocks are publicly sold in the open market at market price, so there is no tax avoidance issue. However, although the selling prices of most unlisted stocks are considerably lower than the amount of tax payment in kind, Company A's unlisted stock with a tax payment in kind at 15.8 billion KRW was sold at 43 billion KRW, and Company B's unlisted stock with a tax payment in kind of 300 million KRW was sold at 3.3 billion KRW in 2014. In the case of Company C, unlisted stock with a tax payment in kind of 500 million KRW was sold at 2 billion KRW. Unusual phenomena also occur, wherein unlisted stocks were sold at a higher price than the amount of tax payment in kind. Predetermined price at the public disposal stage is roughly four times higher than the value of unlisted stocks at the collection stage.

Although this study raises problems in the valuation of unlisted stocks collected as tax by the government, it has several limitations. Polychoric correlations are possible because the variables are measured by ordinally ranked scale. We demand interested future governments to devote efforts toward improving the fair valuation of unlisted stock to support SMEs' sustainability.

The high bidding prices of the buyers, including the company that paid the tax in kind, can restrict the incentive to buy the unlisted stocks and subsequently lead to continuous bidding failure and price reduction of the stocks that will eventually be traded at a lower value than the selling price.

Acknowledgments: We thank the two anonymous reviewers for their constructive suggestions.

Author Contributions: KapSoon Kim suggested the initial idea and conducted the data analysis. SungMan Yoon advised the theoretical framework and edited the manuscript. All authors have reviewed and approved the final manuscript.

Conflicts of Interest: The author declares no conflict of interest. 


\section{References}

1. Lenin, V.I. The tax in kind. Collect. Works 1965, 32, 329-365.

2. Griffin, W.L.; Lacewell, R.D. Long-run implications of a tax in kind to reduce supply and increase income: Comment. Am. J. Agric. Econ. 1973, 55, 670-674. [CrossRef]

3. Kim, K.S.; Yoon, S.M. A study on problems and improvements of valuation method for payment of tax in non-listed stock. Korean Tax. Res. 2016, 33, 95-123. (In Korean) [CrossRef]

4. Lee, J.; Kim, H.J.; Ahn, M.J. The willingness of e-Government service adoption by business users: The role of offline service quality and trust in technology. Gov. Inform. Q. 2011, 28, 222-230. [CrossRef]

5. Barth, M.E.; Clinch, G.; Israeli, D. What do accruals tell us about future cash flows? Rev. Account. Stud. 2016, 21, 768-807. [CrossRef]

6. Hitchen, E.L.; Hitchen, E.L.; Nylund, P.A.; Nylund, P.A.; Ferràs, X.; Ferràs, X.; Mussons, S. Social media: Open innovation in SMEs finds new support. J. Bus. Strateg. 2017, 38, 21-29. [CrossRef]

7. Ohlson, J. A. Earnings, book values, and dividends in equity valuation. Contemp. Account. Res. 1995, 11, 661-687. [CrossRef]

8. Chang, O.H.; Nichols, D.R.; Schultz, J.J. Taxpayer attitudes toward tax audit risk. J. Econ. Psychol. 1987, 8, 299-309. [CrossRef]

9. Heady, E.O. Tax in kind to reduce supply and increase income without government payments and marketing quotas. Am. J. Agric. Econ. 1971, 53, 441-447. [CrossRef]

10. Barnes, P. Stock market scams, shell companies, penny shares, boiler rooms and cold calling: The UK experience. Int. J. Law Crime Justice 2017, 48, 50-64. [CrossRef]

11. Alvaredo, F.; Garbinti, B.; Piketty, T. On the share of inheritance in aggregate wealth: Europe and the USA, 1900-2010. Economica 2017, 84, 239-260. [CrossRef]

12. Hamilton, J.L. Market information and price dispersion: Unlisted stocks and NASDAQ. J. Econ. Bus. 1987, 39, 67-80. [CrossRef]

13. Gassen, J.; Uwe Fülbier, R.; Sellhorn, T. International differences in conditional conservatism-the role of unconditional conservatism and income smoothing. Eur. Account. Rev. 2006, 15, 527-564. [CrossRef]

14. Hung, S.Y.; Chang, C.M.; Yu, T.J. Determinants of user acceptance of the e-Government services: The case of online tax filing and payment system. Govern. Inform. Q. 2006, 23, 97-122. [CrossRef]

15. Reichheld, F.F.; Sasser, W.E. Zero defection: Quality comes to service. Harvard Bus. Rev. 1990, 68, $105-111$.

16. Rusbult, A.; Farrel, D. A longitudinal test of the investment model: The impact on job commitment and turnover of variation in rewards, cost alternatives and investment. J. Appl. Psychol. 1983, 68, 429-438. [CrossRef]

17. Jung, H.S. Relationship between Influential Factors of Making Decision Process and Repurchase Intention. Master's Thesis, Changwon National University, Changwon, Korea, 2004. (In Korean)

18. Li, Z.; Liu, P.Z.; Wang, W.; Xu, C. Using support vector machine models for crash injury severity analysis. Accid. Anal. Prev. 2012, 45, 478-486. [CrossRef] [PubMed]

19. Anarkooli, A.J.; Hosseinpour, M.; Kardar, A. Investigation of factors affecting the injury severity of single-vehicle rollover crashes: a random-effects generalized ordered probit model. Accid. Anal. Prev. 2017, 106, 399-410. [CrossRef] [PubMed]

20. Likert, R. The method of constructing an attitude scale. In Readings in Attitude Theory and Measurement; Wiley: Hoboken, NJ, USA, 1967; pp. 90-95.

(C) 2017 by the authors. Licensee MDPI, Basel, Switzerland. This article is an open access article distributed under the terms and conditions of the Creative Commons Attribution (CC BY) license (http://creativecommons.org/licenses/by/4.0/). 